\title{
Diagnosis Kesalahan Siswa dalam Memahami Materi Faktorisasi Bentuk Aljabar pada Siswa Kelas VIII
}

\author{
Husnul Khatimah ${ }^{1 *}$, Orin Asdarina ${ }^{2}$ \\ ${ }^{1,2}$ STKIP Muhammadiyah, Aceh Barat Daya \\ ${ }^{*}$ husnulkhatimah.mtk@gmail.com
}

\begin{abstract}
Abstrak
Tujuan dari penelitian ini adalah untuk mengetahui kesalahan apa saja yang dilakukan oleh siswa dan usaha guru untuk mengatasi kesalahan dalam memahami materi faktorisasi bentuk aljabar. Jenis kesalahannya ada 3 yaitu: 1) Konseptual; 2) Operasional; 3) Prosedural. Jenis penelitian ini menggunakan metode kuantitatif dan kualitatif dengan menggunakan instrumen tes untuk mengetahui jenis kesalahan pada materi faktorisasi bentuk aljabar serta kusioner dan wawancara untuk mengetahui penyebab kesalahan yang dilakukan berdasarkan persepsi siswa.Subjek penelitiannya yaitu siswa kelas VIII C dengan jumlah 36 siswa. Hasil analisispadaawaban tes menunjukkan jenis-jenis kesalahan siswa dalam memahami materi faktorisasi bentuk aljabar yaitu: kesalahan konseptual mencapai 86,1\%, kesalahan prosedural mencapai 38,8, kesalahan operasional mencapai 97,2\%. Penyebab yang dialami siswa dalam memahami materi faktorisasi bentuk aljabar yaitu: Siswa belum mampu mengingat rumus, kesalahan dalam menerjemahkan soal cerita matematika ke bentuk rumus, kesalahan dalam menyelesaian langkah demi langkah dan kesalahan dalam mengoperasikan (penjumlahan, pengurangan, perkalian dan pembagian) bentuk aljabar. Usaha yang dapat dilakukan untuk mengatasi kesulitan siswa dalam memahami materi faktorisasi bentuk aljabar yaitu: Pemberian pemahaman konsep dasar kepada siswa atau materi matematika terutama pada materi faktorisasi bentuk aljabar, mengilustrasikan hubungan materi yang di ajarkan dengan pengalaman sehari-hari siswa yang didapat siswa dari lingkungan sekitarnya, penggunaan bahasa yang sederhana atau bahasa yang mudah dimengerti siswa dalam menjelaskan materifaktorisasikentuk aljabar, dan pemberiansoal-soal latihan kepada siswa menurut kemampuan siswa dengan soal yang berbeda-beda supaya siswa lebih mengerti dan kreatif dalam menyelesaikan soal dan lebih mudah dalam memahami materi faktorisasi bentik aljabar dengan baik dan sesuai dengan yang diinginkan.
\end{abstract}

Kata Kunci :diagnosis kesalahan siswa, faktorisasi bentuk aljabar.

\begin{abstract}
The purpose of this research is to find out what mistakes made by students and teachers' efforts to overcome errors in understanding the algebraic factorization material. There are 3 types of errors, namely: 1) Conceptual; 2) Operations; 3) Procedural. This type of research uses quantitative and qualitative methods by using test instruments to find out the types of errors in the algebraic and factorial form factorization material and interviews to find out the causes of errors made based on students' perceptions. The research subjects are students of class VIII C with a total of 36 students. The results of the analysis on the test report showed the types of students' mistakes in understanding the algebraic factorization material, namely: conceptual errors reached $86.1 \%$, procedural errors reached 38.8 , operational errors reached $97.2 \%$. The causes experienced by students in understanding the algebraic factorization material material are: Students have not been able to remember formulas, errors in translating mathematical story problems into formula form, errors in completing step by step and errors
\end{abstract}


in operating (addition, subtraction, multiplication, and division) algebraic form. Efforts that can be made to overcome the difficulties of students in understanding algebraic factorization material are: Providing understanding of basic concepts to students or mathematical material, especially in algebraic factorization material, illustrating the relationship of the material taught with the daily experience of students obtained by students from the surrounding environment, the use of simple language or language that is easily understood by students in explaining the algebraic factorization material, and giving practice questions to students according to students' abilities with different questions so that students are more understanding and creative in solving problems and easier in understanding material Factor algebraic benthic well and as desired.

Keywords: diagnosis of student errors, factorization of algebraic forms.

\section{Pendahuluan}

Matematika merupakan mata pelajaran yang sudah diterima sejak pendidikan dasar sampai pendidikan lanjut. Namun, tidak sedikit siswa yang mengalami kesulitan dalam pembelajaran matematika. Menurut Hudojo (2000) "terdapat materi yang dengan mudah dipahami oleh siswa, tetapi juga ada materi yang sulit untuk dipahami karena dimungkinkan terdapat beberapa faktor yang menghambat pemahaman pada siswa, baik faktor internal maupun eksternal".

Faktor internal atau faktor dari dalam diri siswa dapat berupa motivasi, kemampuan intelektual siswa, minat, bakat, dan sebagainya. Faktor eksternal adalah faktor dari luar dapat berupa kondisi lingkungan, keluarga, guru, teman, alat belajar, dan sebagainya (Slameto, 2003). Guru sangat mempengaruhi kesulitan siswa dalam belajar matematika, pertama kurang tepatnya strategi pembelajaran yang digunakan guru matematika dalam menyampaikan pokok bahasan tertentu. Kedua, banyak guru matematika yang cenderung menggunakan metode ceramah dalam menyampaikan materi pelajaran, sehingga menyebabkan siswa merasa bosan dalam pembelajaran matematika.

Berdasarkan hasil observasi awal dengan salah satu guru matematika di MTsN Unggul Susoh bahwa Aljabar merupakan materi yang baru diperkenalkan untuk siswa MTsN karena melalui pembelajaran Aljabar siswa dihadapkan pada peralihan angka menjadi huruf atau simbol sehingga sering terjadi banyak kekeliruan yang ditemukan guru dalam penyelesaian soal-soal yang dilakukan oleh siswa.

Kesalahan merupakan bentuk penyimpangan terhadap hal yang benar, prosedur yang ditetapkan sebelumnya, atau penyimpangan dari sesuatu yang diharapkan. Kesalahan atau kesulitan yang dialami siswa dapat ditelusuri sehingga dapat dilakukan tindakan pencegahan ataupun penanggulangan pada pembelajaran. 
Banyak peneliti terdahulu yang mengkaji kesalahan siswa pada materi aljabar. Hasil penelusuran dari berbagai literatur dan publikasi penelitian tentang kesalahan siswa pada materi aljabar menunjukkan bahwa penelitian-penelitian tersebut masing- masing secara terpisah fokus pada konsepsi variabel, persamaan, pertidaksamaan, atau masalah verbal (soal cerita) dalam aljabar. Para peneliti berupaya untuk mengidentifikasi miskonsepsi berdasarkan salah satu konsep pada materi aljabar dan memberikan penjelasan secara spesifik penyebab kesalahan melalui proses penalaran siswa. Namun, masih relatif sedikit penelitian yang dilakukan untuk menganalisis kesalahan dan kemampuan siswa yang didasarkan pada gabungan konsep-konsep dalam materi aljabar di tingkat sekolahan.

Hasil penelitian terdahulu Suardi (2013), hasil penelitian menunjukkan bahwa "kesalahan siswa dalam membentuk persamaan, menebak tanpa penjelasan, miskanselasi dan lain-lain”. Selanjutnya berdasarkan penelitian Sahriah (2012), hasil penelitian menunjukkan bahwa "kesalahan tidak menyamakan penyebut, kesalahan konsep perkalian silang, kesalahan tidak memfaktorkan".

Menyelesaikan masalah merupakan proses untuk menerima tantangan untuk menjawab masalah. Karena itu mengajar bagaimana menyelesaikan masalah merupakan kegiatan pengajar untuk memberikan motivasi kepada peserta didik agar peserta didik itu bersedia menerima pertanyaan yang menantang itu dan apabila perlu pengajar membimbingnya sampai peserta didik dapat menyelesaikan masalah tersebut (Hudojo, 2000).Lebih jauh Hudojo (2000) menyebutkan bahwa peserta didik akan mengerti masalah bila peserta didik tersebut mengetahui 1) apa yang dibuktikan atau ditanyakan? 2)apa data yang diketahui? dan 3) bagaimana syarat-syaratnya?

Selain memperhatikan langkah-langkah di atas, siswa juga dituntut dalam memahami isi dari suatu soal. Siswa juga diharapkan dapat membuat model atau kalimat matematika. Di samping itu, siswa juga harus mampu memilih rumus yang sesuai dan terampil di dalam melakukan suatu proses perhitungan dan yang tidak kalah penting siswa harus mampu menyimpulkan dari jawaban yang ditemukan.

Kesalahan dapat diartikan sebagai penyimpangan terhadap sesuatu yang benar. Sukirman (2000), menyatakan bahwa "kesalahan merupakan penyimpangan terhadap hal yang benar yang sifatnya sistematis, konsisten maupun insidental". Sedangkan Fredette dan Clement (dalam Sartin, 2005), menyatakan bahwa "kesalahan sebagai suatu kejadian atau tingkah laku yang signifikan dapat diamati berbeda dari kejadian atau tingkah laku yang diharapkan". Kesalahan adalah siswa mengerjakan sesuatu dengan tidak benar. Kesalahan 
adalah suatu bentuk penyimpangan terhadap jawaban yang sebenarnya yang bersifat sistematis (Sahriah et.al, 2012). "Kesalahan siswa dalam menyelesaikan soal matematika berkenaan dengan kesalahan yang dilakukan oleh siswa pada saat menggunakan dan menerapkan konsep, prinsip, dan operasi untuk menyelesaikan soal-soal matematika" (Wijaya \&Masriyah, 2013). Kesalahan yang dilakukan siswa tersebut dapat terjadi pada hasil maupun proses penyelesaian soal (termasuk pada perhitungannya).

Tabel 1. Jenis-Jenis Kesalahan yang dilakukan Siswa dalam Menyelesaikan Soal Matematika dan Indikatornya

\begin{tabular}{|l|l|}
\hline \multicolumn{1}{|c|}{ Kesalahan } & \multicolumn{1}{c|}{ Indikator } \\
\hline a. Konsep & 1) $\begin{array}{l}\text { Kesalahan menentukan teorema atau } \\
\text { rumus untuk menjawab suatu masalah. }\end{array}$ \\
\hline 2) $\begin{array}{l}\text { Penggunaan teorema atau rumus oleh } \\
\text { siswa tidak sesuai dengan kondisi } \\
\text { prasyarat berlakunya rumus. }\end{array}$ \\
\hline b. Kesalahan menggunakan data & 1) $\begin{array}{l}\text { Tidak menggunakan data yang } \\
\text { seharusnya dipakai. }\end{array}$ \\
\hline 2) Kesalahan interpretasi bahasa & 3) $\begin{array}{l}\text { Kesalahan memasukkan data ke } \\
\text { variabel. } \\
\text { dalam menjawab suatu masalah. }\end{array}$ \\
\hline d. Kesalahan teknis & 1) $\begin{array}{l}\text { Kesalahan dalam menyatakan bahasa } \\
\text { sehari-hari dalam bahasa matematika. }\end{array}$ \\
\hline 2) $\begin{array}{l}\text { Kesalahan menginterpretasikan } \\
\text { symbol-simbol, grafik, dan table ke } \\
\text { dalam bahsa matematika. }\end{array}$ \\
\hline e. kesalahan penarikan kesimpulan & 1) $\begin{array}{l}\text { Kesalahan perhitungan atau } \\
\text { komputasi. } \\
\text { Kesalahan memanipulasi operasi } \\
\text { aljabar }\end{array}$ \\
\hline 2) & 2) $\begin{array}{l}\text { Melakukan penyimpulan tanpa alasan } \\
\text { pendukung yang benar. } \\
\text { Melakukan penyimpulan pernyataan } \\
\text { yang tidak sesuai dengan penalaran } \\
\text { logis. }\end{array}$ \\
\hline
\end{tabular}

Rode (2013) membagi jenis-jenis kesalahan siswa menjadi dua macam, yaitu: “1) kesalahan konseptual, yaitu kesalahan yang dilakukan dalam menafsirkan istilah, konsep dan prinsip atau salah dalam menggunakan istilah, konsep dan prinsip dan 2) kesalahan prosedural, yaitu kesalahan dalam menyusun langkah-langkah yang hirarkis sistematis untuk menjawab suatu masalah".

Menurut Najiyah (2000) menggolongkan kesalahan menjadi tiga jenis kesalahan, yaitu: 1) Kesalahan konseptual, yaitu kesalahan yanng dibuat siswa dalam menggunakan 
konsep-konsep yang terkait dengan materi; 2) Kesalahan prinsip, yaitu kesalahan dalam menggunakan aturan-aturan atau rumus-rumus matematika dan kesalahan dalam menyusun langkah-langkah yang hirarkis sistematis untuk menjawab suatu soal; 3) Kesalahan operasional, yaitu kesalahan dalam melakukan operasi atau perhitungan. Adapun jenis kesalahan yang akan dianalisis pada penelitian ini memakai pendapat yang dikemukakan oleh Najiyah tersebut, yakni sebagai berikut:

1) Kesalahan konseptual, yaitu kesalahan yanng dibuat siswa dalam menggunakan konsepkonsep yang terkait dengan materi faktorisasi bentuk aljabar, seperti:

a. salah dalam memahami makna soal faktorisasi bentuk aljabar.

b. salah dalam menerjemahkan soal faktorisasi bentuk aljabar ke dalam kalimat matematika.

c. salah tentang konsep peubah faktorisasi bentuk aljabar yang digunakan untuk membuat model atau kalimat matematika.

2) Kesalahan prosedural, yaitu kesalahan dalam menggunakan aturan-aturan atau rumusrumus dan kesalahan dalam menyusun langkah-langkah yang hirarkis sistematis untuk menjawab suatu soal faktorisasi bentuk aljabar, seperti:

a. salah dalam menggunakan aturan-aturan yang ada pada metode eliminasi dan subtitusi faktorisasi bentuk aljabar.

b. salah dalam penarikan kesimpulan dalam menentukan jawaban akhir soal faktorisasi bentuk aljabar.

3) Kesalahan operasional, yaitu kesalahan dalam melakukan operasi atau perhitungan, baik penjumlahan, pengurangan, perkalian, maupun pembagian pada materi faktorisasi bentuk aljabar, seperti:

a. Melakukan operasi yang sesuai (penjumlahan, pengurangan, perkalian atau pembagian).

b. Menentukan hasil dari operasi yang benar.

Berdasarkan latar belakang yang telah dipaparkan di atas, maka rumusan masalah dalam penelitian ini adalah apa saja kesalahan yang dilakukan oleh siswa kelas VIII MTsN Unggul Susoh dalam memahami materi faktorisasi bentuk aljabar? Apa penyebab siswa kelas VIII MTsN Unggul Susoh melakukan kesalahan dalam memahami materi faktorisasi bentuk aljabar?Apa saja usaha yang dapat dilakukan untuk mengatasi kesalahan siswa dalam memahami materi faktorisasi bentuk aljabar pada siswa kelas VIII MTsN Unggul Susoh? 


\section{Metode Penelitian}

Jenis penelitian ini adalah jenis penelitian deskriptif kualitatif, yaitu tampilan yang berupa kata-kata lisan atau tertulis yang dicermati oleh peneliti, dan benda-benda yang diamati sampai detailnya agar dapat ditangkap makna yang tersirat dalam dokumen atau bendanya. (Arikunto, 2007). Subjek penelitian dalam penelitian ini penulis mengambil kelas VIIIdengan jumlah 36 siswa MTsN Unggul Susoh.

Dalam mengumpulkan data penelitian, diperlukan instrumen penelitian, Adapun instrumen penelitian yang penulis gunakan dalam membahas skripsi ini adalah tes dan wawancara. Data yang diperoleh dari hasil tes diolah dengan menggunakan rumus skala likert (Arikunto, 2010) sebagai berikut:

$$
P=\frac{F}{N} \times 100 \%
$$

Keterangan:

P : Persentase jumlah soal yang dijawab responden.

F : Frekuensi alternatif jawaban.

$\mathrm{N}$ : Jumlah responden.

$100 \%$ : Nilai konstanta.

Berdasarkan hasil persentase yang telah diketahui kemudian hasil tersebut dikategorikan sebagai berikut:

$$
\begin{aligned}
& 0 \%-29 \%=\text { sangat kurang } \\
& 30 \%-49 \%=\text { kurang } \\
& 50 \%-69 \%=\text { sedang } \\
& 70 \%-89 \%=\text { baik } \\
& 90 \%-100 \%=\text { sangat baik }
\end{aligned}
$$

Triangulasi data dalam penelitian ini adalah data hasil dari tes dan wawancara. Dalam menjawab soal tentang faktorisasi bentuk Aljabar ada beberapa keabsahan dalam mengecek kesalahan yang dilakukan oleh siswa melalui tes, antara lain dapat dilihat dari tabel di bawah ini. 
Tabel 2. Pedoman Analisis Kesalahan Data

\begin{tabular}{|l|l|}
\hline $\begin{array}{c}\text { Jenis } \\
\text { Kesalahan }\end{array}$ & \multicolumn{1}{|c|}{ Indikator } \\
\hline Konseptual & d. $\begin{array}{l}\text { Salah dalam menerjemahkan soal faktorisasi bentuk } \\
\text { aljabar ke dalam kalimat matematika. }\end{array}$ \\
& $\begin{array}{l}\text { Salah tentang konsep peubah faktorisasi bentuk } \\
\text { aljabar yang digunakan untuk membuat model atau } \\
\text { kalimat matematika. }\end{array}$ \\
\hline Prosedural & a. $\begin{array}{l}\text { Salah dalam menggunakan aturan-aturan yang ada } \\
\text { pada metode eliminasi dan subtitusi faktorisasi } \\
\text { bentuk aljabar. }\end{array}$ \\
\hline b. $\begin{array}{l}\text { Salah dalam penarikan kesimpulan dalam } \\
\text { menentukan jawaban akhir soal faktorisasi bentuk } \\
\text { aljabar. }\end{array}$ \\
\hline Operasional & $\begin{array}{l}\text { Salah dalam melakukan operasi yang tidak sesuai } \\
\text { (penjumlahan, pengurangan, perkalian atau } \\
\text { pembagian). }\end{array}$ \\
d. Salah dalam menentukan hasil dari operasi yang \\
benar.
\end{tabular}

\section{Hasil dan Pembahasan}

Berdasarkan hasil tes yang telah dilaksanakan dari tanggal 5-15 September 2017 di MTsN Unggul Susoh didapatkan kepastiannya bahwa soal tersebut valid dan layak untuk dilanjutkan penelitian lebih lanjut. Untuk melihat hasil kevalidan soal tes dengan menggunakan lembar validasi tes kesalahan dalam menyelesaikan soal dapat dilihat pada lampiran.

Tabel 3. Data Hasil Penilaian Kesalahan Jawaban Siswa

\begin{tabular}{|c|c|c|c|}
\hline No & Jenis Kesalahan & Frekuensi & Persentase \\
\hline 1 & Kesalahan Konseptual & 31 & $86,1 \%$ \\
\hline 2 & Kesalahan Prosedural & 14 & $38,8 \%$ \\
\hline 3 & Kesalahan Operasional & 35 & $97,2 \%$ \\
\hline
\end{tabular}

Dari tabel di atas dapat diketahui hasil dari kemampuan siswa yang kurang memahami materi faktorisasi bentuk aljabar sebanyak $86,1 \%$, siswa yang mengalami kesalahan prosedural 38,8\% dan siswa yang mengalami kesalahan operasional 97,2\%.

\section{Kesalahan yang di lakukan oleh Siswa Kelas VIII MTsN Unggul Susoh dalam memahami Materi Faktorisasi Bentuk Aljabar}

Berdasarkan hasil penelitian yang telah dilakukan, diperoleh hasil bahwa siswa mengalami kesalahan dalam memahami materi faktorisasi bentuk aljabar. Jenis kesalahan ini 
meliputi kesalahan konseptual, kesalahan prosedural dan kesalahan operasional. Pada hasil penelitian terlihat bahwa banyak terjadi kesalahan pada kesalahan prosedural. Kesalahan tersebut dapat dilihat pada setiap butir soal.

Jenis-jenis kesalahan yang palingbanyak dilakukan siswa dalam menjawab soal tes yaitu:

Soal nomor 1.a jenis kesalahannya $\mathrm{kp} b$

Indikatornya: - Salah dalam penarikan kesimpulan dalam menentukan jawaban akhir soal faktorisasi bentuk aljabar.

Hal itu dapat dilihat pada gambar jawaban siswa berikut:

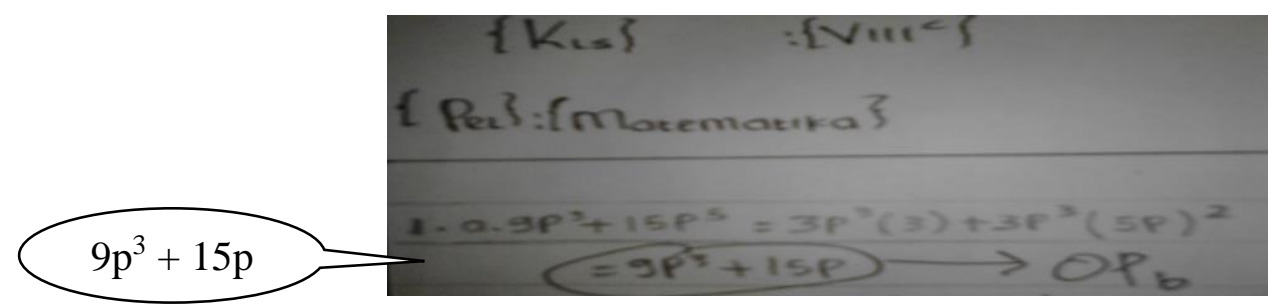

Gambar 4.2.1 Kesalahan Jawaban Akhir

Gambar 1. Hasil Jawaban Siswa

Pada soal nomor 1a ini kesalahan yang dilakukan oleh siswa yaitu kesalahan jawaban akhir. Kesalahan jawaban akhir ini disebabkan karena kurangnya ketelitian siswa dalam perkalian silang dan pangkatnya hingga mengakibatkan jawaban akhirnya salah dan jawaban yang benarnya ialah: $3 p^{3}\left(3+5 p^{2}\right)$.Kemudian peneliti juga melakukan wawancara dengan siswa tersebut untuk mengetahui lebih jelas penyebab siswa tersebut melakukan kesalahan. Hasil wawancaranya seperti yang terlihat dibawah ini:

P: "Apakah menurut anda soal nomor 1a ini sulit?"

S: "Tidak."

P: "Kalau memang tidak, kenapa hasil akhir jawaban anda salah?"

S: "Itu hanya salah keliru."

P: "Kenapa anda bisa keliru?"

S: "Karena saya kurang teliti dalam menentukan hasil akhirnya."

Dari hasil wawancara diatas, dapat disimpulkan bahwa siswa tersebut keliru atau tidak teliti dalam menjawab soal.

Soal nomor 1.b jenis kesalahannya kob

Indikatornya: - Menentukan hasil dari operasi yang benar

Hal itu dapat dilihat dari gambarjawaban siswa berikut: 


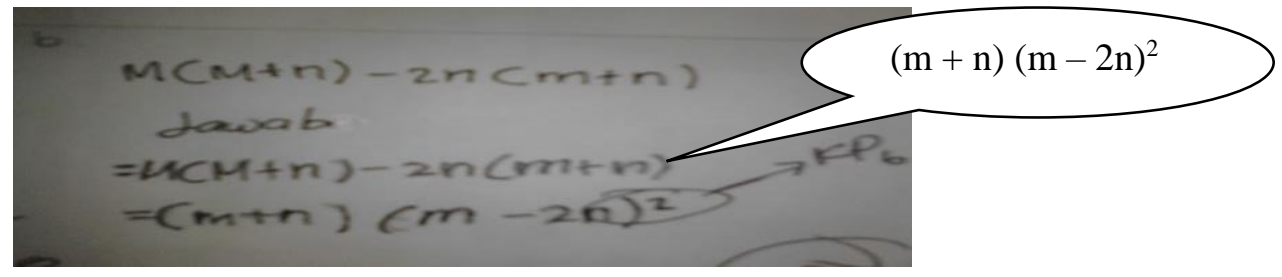

Gambar 2. Kesalahan Operasional

Pada soal nomor $1 \mathrm{~b}$ ini kesalahan yang dilakukan oleh siswa yaitu kesalahan jawaban akhir. Kesalahan jawaban akhir ini disebabkan karena kurangnya ketelitian siswa dalam pangkatnya hingga mengakibatkan jawaban akhirnya salah dan jawaban yang benarnya ialah: $(m+n)(m-2 n)$.

Selanjutnya peneliti juga melakukan wawancara dengan siswa yang jawabannya tertera di atas dan hasilnya sebagai berikut:

P:" Apakah menurut anda soal nomor $1 \mathrm{~b}$ ini sulit?"

S: "Bukannya sulit tapi ragu dalam perkaliannya."

P:"Perkalian yang mananya sulit?"

S: "Perkalian yang tidak sama jadi saya keliru dalam menjawab hasil akhirnya." Dari hasil wawancara diatas, peneliti dapat menyimpulkan bahwa siswa tersebut tidak teliti dalam menjawab soal.

Soal nomor 1.c jenis kesalahan $\mathrm{kk}_{\mathrm{b}}$

Indikatornya: - Salah tentang konsep peubah faktorisasi bentuk aljabar yang di gunakan untuk membuat model atau kalimat matematika.

Hal itu dapat dilihat pada gambar jawaban siswaberikut:

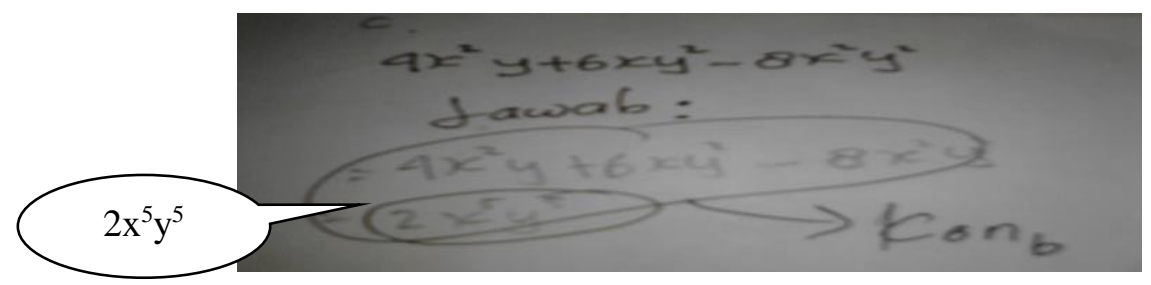

Gambar 3. Kesalahan Konseptual

Pada soal 1c ini, kesalahan yang di lakukan oleh siswa terdapat pada konsepnya, sehingga siswa salah di langkah pertama dan jawaban yang benar ialah: $2 x y(2 x)+2 x y(3 y)-$ $2 x y(4 x y)$.Berikutnya peneliti melanjutkan instrumen selanjutnya yaitu wawancara dengan siswa yang bersangkutan dan hasil wawancaranya seperti yang terlihat dibawah:

P: "Apakah menurut anda soal nomor 1c ini sulit?"

S: "Iya, sulit." 
P: "Kenapa anda mengatakan sulit?"

S: "Karena lawan perkaliannya itu saya tidak tau."

P: "Apakah maksud anda konsepnya?"

S: "Iya.

Dari hasil wawancara diatas dapat peneliti simpulkan bahwa siswa tersebut tidak memahami konsep dari soal 1c ini.

Soal nomor 1.d jenis kesalahan $\mathrm{kk}_{\mathrm{b}}$

Indikatornya: - Salah tentang konsep peubah faktorisasi bentuk aljabar yang digunakan untuk membuat model atau kalimat matematika.

Hal itu dapat dilihat pada gambar jawaban siswa berikut:

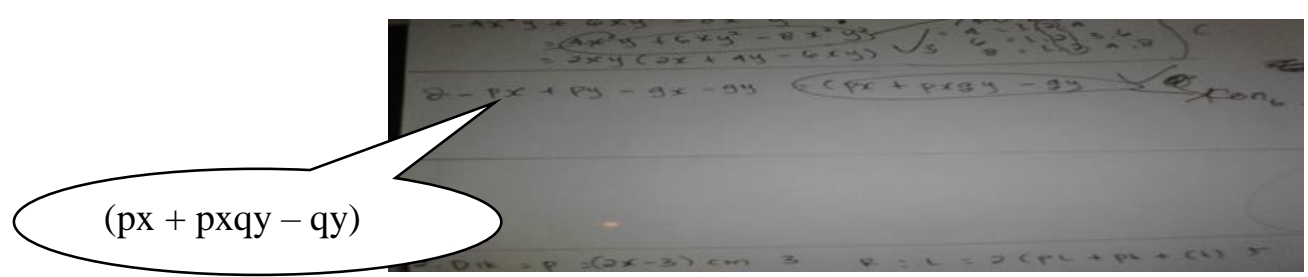

Gambar 4. Kesalahan Konseptual

Pada soal 1d ini, kesalahan yang di lakukan oleh siswa terdapat pada konsepnya, sehingga siswa salah di langkah pertama dan jawaban yang benar ialah: $\mathrm{p}(\mathrm{x}+\mathrm{y})-\mathrm{q}(\mathrm{x}-$ y).Setelah mengetahui kesalahan yang dilakukan siswa maka peneliti melanjutkan instrumen selanjutnya yaitu wawancara dengan siswa yang bersangkutan dan hasil wawancaranya seperti yang terlihat dibawah:

P:"Apakah soal nomor 1d ini sulit bagi anda?"

S: "Iya."

P: "Kenapa anda katakan sulit?"

S: "Karena perkaliannya itu."

P: "Perkalian yang bagaimana dikatakan sulititu?"

S: "ketika menentukan lawan perkaliannya."

Dari hasil wawancara tersebut dapat disimpulkan bahwa siswa tersebut tidak memahamitentang konsep dari soal $1 \mathrm{~d}$ ini.

Soal 1e jenis kesalahan $\mathrm{kk}_{\mathrm{b}}$

Indikatornya: Salah tentang konsep peubah faktorisasi bentuk aljabar yang di gunakan untuk membuat model atau kalimat matematika. 


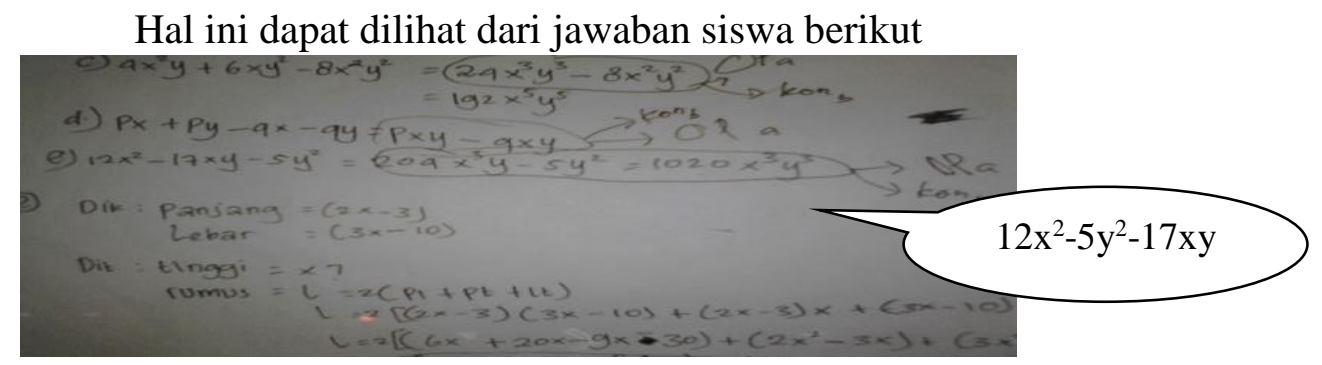

Gambar 5. Kesalahan Konseptual

Pada soal 1e ini, kesalahan yang di lakukan oleh siswa terdapat pada konsepnya, sehingga siswa salah di langkah pertama dan jawaban yang benar ialah: $12 x^{2}-20 x y+3 x y-$ $5 y$. Kemudian peneliti melanjutkan instrumen selanjutnya yaitu wawancara dengan siswa yang bersangkutan dan hasil wawancaranya seperti yang terlihat dibawah:

P:"Apakah soal nomor 1e ini sulit bagi anda?"

S: "Iya."

P: "Kenapa anda katakan sulit?"

S: "Karena perkaliannya."

P: "Perkalian yang bagaimana dikatakan sulititu?"

S: "Ketika menentukan perkaliannya."

P: "Perkalian yang bagaimana?"

S: "Perkalian silangnya."

Dari hasil wawancara tersebut dapat disimpulkan bahwa siswa tersebut tidak memahami tentang konsep dari soal 1e ini.

Soal nomor 2 jenis kesalahan $\mathrm{ko}_{\mathrm{a}}$

Indikatornya:Melakukan operasi yang sesuai (penjumlahan, pengurangan, perkalian atau pembagian).

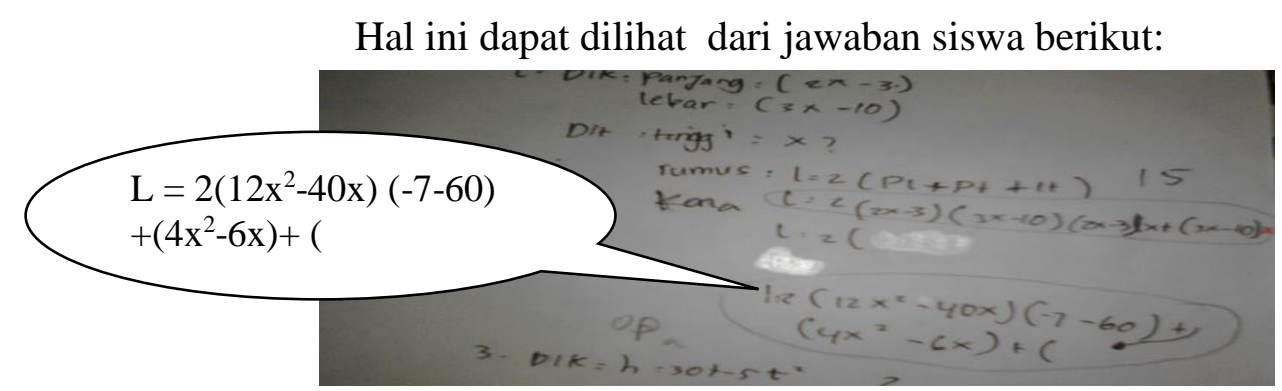

Gambar 6. Kesalahan Operasional

Pada soal 2 ini, kesalahan yang di lakukan oleh siswa terdapat pada perkaliannya dan jawaban yang benar ialah: $\left[\left(6 x^{2}+20 x-9 x-30\right)+\left(2 x^{2}-3 x\right)+\left(3 x^{2}-10 x\right)\right]$.Setelah mengetahui kesalahan yang dilakukan siswa maka peneliti melanjutkan instrumen selanjutnya yaitu wawancara dengan siswa yang bersangkutan dan hasil wawancaranya seperti yang terlihat dibawah: 
P:"Apakah soal nomor 2 ini sulit bagi anda?"

S: "Iya."

P: "Kenapa anda katakan sulit?"

S: "Karena perkaliannya."

P: "Perkalian yang bagaimana dikatakan sulit itu?"

S: "Ketika menentukan perkalian silangnya."

Dari hasil wawancara tersebut dapat disimpulkan bahwa siswa tersebut bingung dengan perkalian silangnya.

Soal nomor $3 \mathrm{a}$ jenis kesalahan kob

Indikatornya:- Menentukan hasil dari operasi yang benar

Hal ini dapat dilihat pada gambar jawaban berikut:

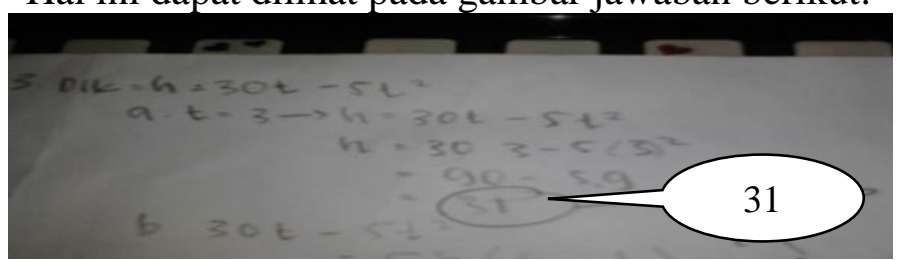

Gambar 7. Kesalahan Operasional

Pada soal nomor 3a ini kesalahan yang dilakukan oleh siswa yaitu kesalahan jawaban akhir. Kesalahan jawaban akhir ini disebabkan karena kurangnya ketelitian siswa dalam pengurangan hingga mengakibatkan jawaban akhirnya salah dan jawaban yang benarnya ialah: 45meter. Untuk berikutnya peneliti melanjutkan instrumen selanjutnya yaitu wawancara dengan siswa yang bersangkutan dan hasil wawancaranya seperti yang terlihat dibawah:

P: "Apakah menurut anda soal nomor 3a ini sulit?"

S: "Tidak"

P: "Jika tidak sulit, kenapa jawaban akhir anda salah?"

S: "Karna sayatidak teliti dalam mengurangakan hasil akhirnya"

Dari hasil wawancara diatas, peneliti dapat menyimpulkan bahwa siswa tersebut tidak teliti dalam menjawab soal.

Soal nomor $3 \mathrm{~b}$ jenis kesalahan $\mathrm{kk}_{\mathrm{a}}$

Indikatornya: - Salah dalam menerjemahkan soal faktorisasi bentuk aljabar ke dalam kalimat matematika.

Hal ini dapat dilihat dari jawaban siswa berikut:

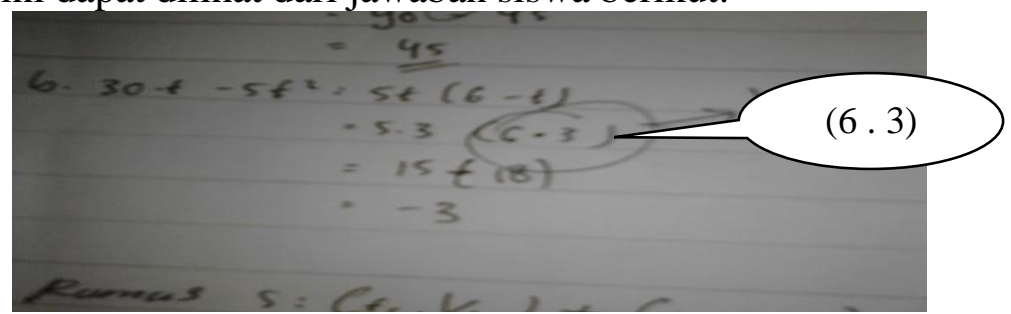

Gambar8. Kesalahan Konseptual 
Pada soal nomor 3 b ini kesalahan yang dilakukan oleh siswa yaitu kesalahan dalam menerjemahkan soal. Kesalahan dalam menerjemahkan soal ini disebabkan karena kurangnya latihan siswa dalam menjawab soal hingga mengakibatkan ketidak sesuaian jawaban dengan rumus dan jawaban yang benarnya ialah: $=5.3(6-3)$. Setelah mengetahui kesalahan yang dilakukan siswa maka peneliti melanjutkan instrumen selanjutnya yaitu wawancara dengan siswa yang bersangkutan dan hasil wawancaranya seperti yang terlihat dibawah:

P: "Apakah menurut anda soal nomor $3 b$ ini sulit?"

S: "Tidak."

P: "Jika tidak kenapa jawaban anda salah?"

S:"'Itu hanya kurang mengingat konsep saja dan ragu-ragu."

P: "Kenapa anda bisa ragu-ragu?"

S: "Karena kurang ingat rumus, apakah itu kali atau kurang."

Dari hasil wawancara diatas, peneliti dapat menyimpulkan bahwa siswa tersebut tidak teliti dan masih kurang dalam mengingat rumus. Soal nomor $4 \mathrm{a}$ jenis kesalahan $\mathrm{kk}_{\mathrm{a}}$ Indikatornya: - Salah dalam menerjemahkan soal Faktorisasi bentuk aljabar ke dalam kalimat matematika.

Hal ini dapat dilihat dari gambar jawaban siswa berikut:

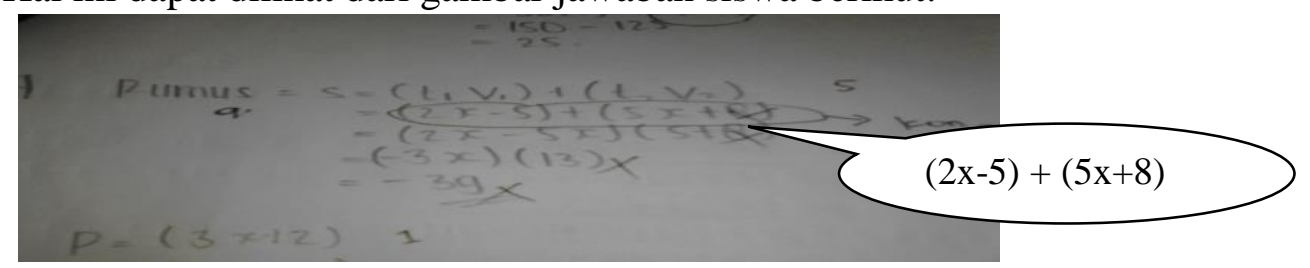

Gambar 9.Kesalahan Konseptual

Pada soal nomor 4a ini kesalahan yang dilakukan oleh siswa yaitu kesalahan dalam menerjemahakan soal. Kesalahan dalam menerjemahkan soal ini disebabkan karena kurangnya latihan siswa dalam menjawab soal hingga mengakibatkan ketidaksesuaian jawaban dengan rumus dan jawaban yang benarnya ialah: $S=(2 x-5) 3+(5 x+8)$ 4.Untuk selanjutnya peneliti melakukan wawancara dengan siswa tersebut untuk mengetahui lebih jelas penyebab siswa tersebut melakukan kesalahan. Berikut hasil wawancaranya:

P: "Apakah menurut anda soal nomor 4a ini sulit?"

S: "Sulit."

P: "Dimananya anda merasa sulit?"

S: "Dibagian memasukkan angka kedalam rumus"

Dari hasil wawancara diatas, peneliti dapat menyimpulkan bahwa siswa tersebut belum bisa menyesuaikan soal dengan rumus

Soal nomor $4 \mathrm{~b}$ jenis kesalahan $\mathrm{kk}_{\mathrm{a}}$

Indikatornya: : - Salah dalam menerjemahkan soal Faktorisasi bentuk aljabar ke dalam kalimat matematika. 


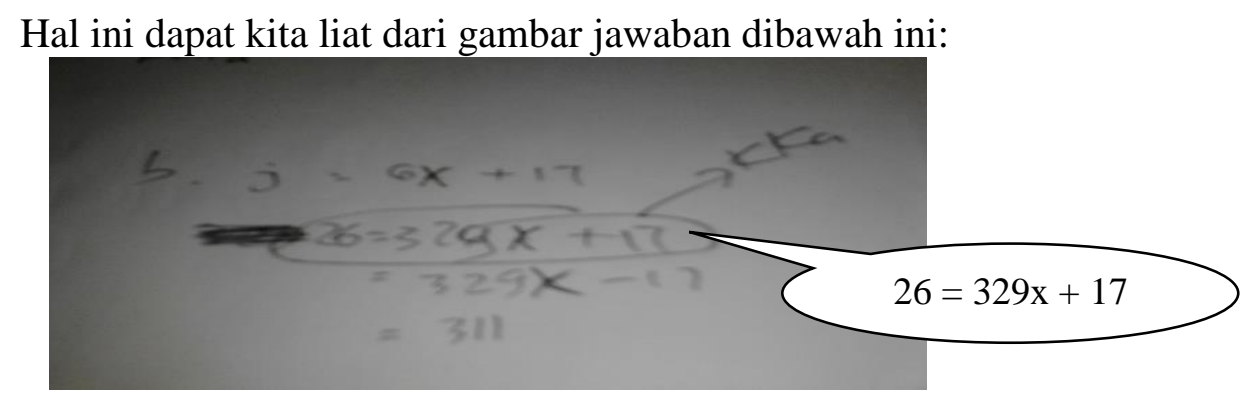

Gambar 10. Kesalahan Konseptual

Pada soal nomor 4b ini kesalahan yang dilakukan oleh siswa yaitu kesalahan dalam menerjemahakan soal. Kesalahan dalam menerjemahkan soal ini disebabkan karena kurangnya latihan siswa dalam menjawab soal hingga mengakibatkan ketidaksesuaian jawaban dengan rumus dan jawaban yang benarnya ialah: $329=26 x+17$. Setelah mengetahui kesalahan yang dilakukan siswa maka peneliti melanjutkan instrumen selanjutnya yaitu wawancara dengan siswa yang bersangkutan dan hasil wawancaranya seperti yang terlihat dibawah:

P: "Apakah menurut anda soal nomor $4 \mathrm{~b}$ ini sulit?"

S: "Sulit."

P: "Dimananya anda merasa sulit?"

S: "Dibagian memasukkan angka kedalam rumus."

Dari hasil wawancara diatas, peneliti dapat menyimpulkan bahwa siswa tersebut belum bisa menyesuaikan soal dengan rumus

Soal nomor 5 a jenis kesalahan kob

Indikatornya:Menentukan hasil dari operasi yang benar

Hal ini bisa kita lihat pada gambar jawaban di bawah ini:

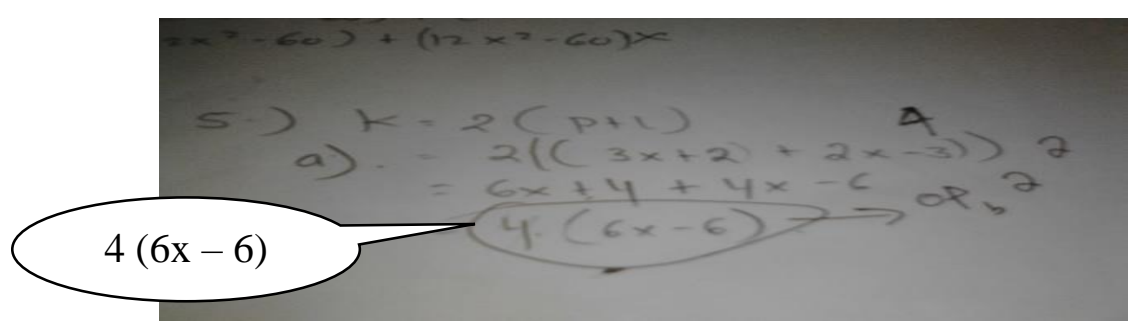

Gambar 11. Kesalahan Operasional

Pada soal nomor 5a ini kesalahan yang dilakukan oleh siswa yaitu kesalahan jawaban akhir. Kesalahan jawaban akhir ini disebabkan karena kurangnya ketelitian siswa dalam pengurangan dan penjumlahan hingga mengakibatkan jawaban akhirnya salah dan jawaban yang benarnya ialah: $10 \mathrm{x}-2$. Untuk mengetahui penyebab kesalahan yang dilakukan siswa tersebut, maka peneliti melakukan instrumen selanjutnya yaitu melakukan wawancara kepada siswa tersebut. Hasil wawancaranya sebagai berikut: 
P: "Apakah menurut anda soal nomor 5a ini sulit?"

S: "Tidak."

P: "Jika tidak sulit, kenapa jawaban akhir anda salah?"

S: "Karena saya tidak teliti dalam mengurangkan dan menjumlahkan hasil akhirnya."

Dari hasil wawancara diatas, peneliti dapat menyimpulkan bahwa siswa tersebut tidak teliti dalam menjawab soal. Soal nomor $5 \mathrm{~b}$ jenis kesalahan $\mathrm{kk}_{\mathrm{a}}$

Indikatornya: - Salah dalam menerjemahkan soal faktorisasi bentuk aljabar ke dalam kalimat matematika.

Hal ini dapat dilihat dari jawaban siswa berikut:

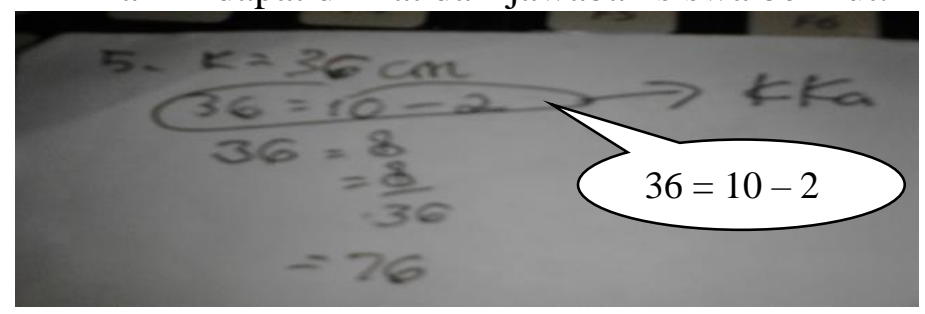

Gambar 12. Kesalahan Konseptual

Pada soal nomor 5b ini kesalahan yang dilakukan oleh siswa yaitu kesalahan dalam menerjemahakan soal. Kesalahan dalam menerjemahkan soal ini disebabkan karena kurangnya latihan siswa dalam menjawab soal hingga mengakibatkan ketidaksesuaian jawaban dengan rumus dan jawaban yang benarnya ialah: 36=10x -2 . Kemudian peneliti juga melakukan wawancara terhadap siswa tersebut, supaya peneliti mengetahui penyebab kesalahan yang siswa lakukan. Berikut hasil wawancaranya:

P:“Apakah menurut anda soal nomor 5b ini sulit?”

S:“Sulit."

P:"Dimananya anda merasa sulit?"

S:" Dibagian memasukkan angka kedalam rumus."

Dari hasil wawancara diatas, peneliti dapat menyimpulkan bahwa siswa tersebut belum bisa menyesuaikan soal dengan rumus.Setelah peneliti melakukan penelitian dan mendapatkan hasilnya, peneliti melakukan wawancara kepada siswa yang mendapatkan nilai terendah. Mereka mengatakan bahwa sering mengalami kesulitan dalam memahami materi, memahami rumus, sering keliru dalam penjumlahan, dalam memahami soal,dan memasukkan rumus ke dalam soal.

\section{Usaha yang dapat dilakukan untuk Mengatasi Kesalahan Siswa dalam Memahami Materi Faktorisasi Bentuk Aljabar pada Siswa Kelas VIII MTsN Unggul Susoh}

Berdasarkan dari hasil penelitian, maka peneliti mengharapkan kepada guru agar lebih banyak memberikan soal-soal latihan yang beragam mengenai materi faktorisasi bentuk 
aljabar agar siswa mampu menyelesaikan soal dengan berbagai tingkat kesalahan yang berbeda-beda. Apabila guru menemukan siswanya mendapatkan kesulitan dalam mengerjakan soal-soal tersebut, maka guru harus mengamati apa penyebabnya. Usaha yang dapat dilakukan oleh guru antara lain: dengan memperhatikan jawaban siswanya apabila lebih dari satu siswa yang mengalami kesulitan belajar yang sama, maka upaya guru untuk memperbaiki ini hendaknya dibagi kelompok, dengan setiap anggota itu bersifat heterogen supaya mereka bisa secara bersama-sama untuk saling bertukar informasi kepada team satu kelompoknya.

Oleh karena itu, maka usaha untuk mengatasi kesalahan siswa dalam memahami materi faktorisasi bentuk aljabar ini ialah: 1)siswa lebih mandiri untuk menyelesaikan sendiri soal-soal yang diberikan guru ataupun yang ada di buku, 2) gurumampu mengaitkan pelajaran materi faktorisasi ini kedalam kehidupan sehari-hari, 3) guru sebaiknya memperbaiki cara mengajarnya dalam mengajar sehingga metode pengajaran yang digunakan disukai siswa.

\section{Simpulan dan Saran}

Berdasarkan hasil penelitian dan pembahasan, maka dapat disimpulkan bahwa:

1. Kesalahan yang terjadi antara lain:

- Kesalahan konseptual mencapai 86,1\% yaitu a) salah dalam menerjemahkan soal faktorisasi bentuk aljabar kedalam kalimat matematika, b) salah dalam konsep peubah faktorisasi bentuk aljabar yang digunakan untuk membuat model atau kalimat matematika.

- Kesalahan prosedural mencapai $38,8 \%$ yaitu a) salah dalam menggunakan aturanaturan yang ada pada metode eliminasi dan subtitusifaktorisasi bentuk aljabar, b) salah dalam penarikan kesimpulan dalam menentukan jawaban akhir soal faktorisasi bentuk aljabar.

- Kesalahan operasional mencapai 97,2\% yaitu a) salah dalam melakukan operasi yang tidak sesuai (penjumlahan, pengurangan, perkalian atau pembagian), b) salah dalam menentukan hasil dari operasi yang benar.

2. Usaha yang dapat dilakukan untuk mengatasi kesulitan siswa dalam memahami materi faktorisasi bentuk aljabar yaitu:

- Dalam mengajarkan konseptual kepada siswa atau materi matematika terutama pada materi faktorisasi bentuk aljabar, guru harus mampu menyambungkan 
konseptual atau materi yang di ajarkan dengan pengalaman sehari-hari siswa yang didapat siswa dari lingkungan sekitarnya.

- Seorang guru dapat menggunakan bahasa yang sederhana atau bahasa yang mudah dimengerti siswa dalam menjelaskan materi faktorisasi bentuk aljabar.

- Guru dapat memberikan soal-soal latihan kepada siswa menurut kemampuan siswa dengan soal yang berbeda-beda supaya siswa lebih mengerti dan kreatif dalam menyelesaikan soal dan lebih mudah dalam memahami materi faktorisasi bentuk aljabar dengan baik dan sesuai dengan yang diinginkan.

3. Kepada sekolah hendaknya mengadakan evaluasi tentang analisis kesalahan siswa disetiap pertengahan semester agar dapat meningkatkan mutu pembelajaran di sekolah.

\section{Referensi}

Arikunto, Suharsimi. 2007. Prosedur Penelitian Suatu Pendekatan Praktek. Jakarta: Rineka Karya

Hudojo, H. 2000. Strategi Mengajar Belajar Matematika, Malang

Najiyah, F. 2000. Analisis Kesalahan Siswa dalam Menyelesaikan Soal Matematika Pokok Bahasan Logaritma di Kelas III A SLTP Nusantara Gresik, Skripsi, UNESA

Rode, R.G. 2013. Analisis Kesalahan dan Solusinya Dalam Menyelesaikan Soal Matematika, Malang: Wisnuwardhana. Skripsi Sarjana Pendidikan

Sahriah, Sitti, et.al. 2012. Analisis Kesalahan Konseptual Siswa Dalam Menyelesaikan Soal Matematika Materi Operasi Pecahan Bentuk Aljabar Kelas VIII SMP Negeri 2 Malang, Jurnal. Malang: UM

Sartin. 2005. Analisis Kesalahan Siswa Kelas V Sekolah Dasar Dalam Menyelesaikan Soal Cerita Yang Memuat Pecahan Desimal. Tesis, Jurusan Matematika Fakultas MIPA: Universitas Negeri Surabaya

Slameto. 2003. Belajar dan Faktor-faktor yang Mempengaruhinya, Cet. III, Jakarta: Rineka Cipta

Suardi. 2013. (http://contohskripsi-ptk-tesis makalah. blogspot. com/2014/02/ptk-sd-163Analisis-Kesalahan-dan-Miskonsepsi-Siswa.html.

Sukirman. 2005. Identifikasi Kesalahan-Kesalahan Yang Diperbuat Siswa Kelas III SMP Pada Setiap Aspek Penguasaan Bahan Pelajaran Matematika, Surabaya: Tesis PPS IKIP Surabaya

Wijaya, A. A. \& Masriyah. 2013. Analisis Kesalahan Siswa dalam Menyelesaikan Soal Cerita Sistem Persamaan Linear Dua Variabel, MATHEdunesa, Jurnal. ISO 690 